\title{
O PATOLINO
}

Valter Rodrigues é doutorando no Programa de Literatura, Cultura e Contemporaneidade da PUC-Rio.

E-mail: alpoetaval@gmail.com

\section{Ô Joooorge!}

Não havia quem não ouvisse e não identificasse o velho Bira no seu brado ao Patolino. Invariavelmente se dava por volta das seis da tarde, depois de um dia de trabalho pesado na obra do metrô. Encostava a surrada bicicleta na cerca de madeiras que limitava a entrada ao terreno, onde junto a outros cinco barracos, todos de familiares, havia erguido o dele, e fazia ressoar o nome do filho em alto som.

\section{_ Ô Joooorge!}

Fora marcante para toda a vizinhança o dia em que a mãe de Jorge e Giovana resolveu ir embora. Ninguém nunca soube o real motivo que a moveu para tal decisão, mas o fato é que foi de partir o coração do mais gélido ser humano que tenha testemunhado a cena. Primeiro, as crianças na casa dos seis, sete anos, impotentes e inconsoláveis, agarradas a ela pela cintura, suplicando “mãe, mãe, não vai!". Ela, por sua vez, irredutível, embora em prantos, até com certa rispidez se desvencilhava dos filhos, prosseguindo na condução dos seus pertences até o táxi que a aguardava. Noutro plano, afastado alguns metros, de pé, no 
alto da pedra que principiava o caminho para o barraco, em completo desalento, a figura robusta e rústica de Bira, àquele momento tão fragilizado pelo pranto e, sobretudo, pelo vazio que lhe preenchia o espírito e o lar. Dos olhos, as lágrimas que fluíam incontidas eram rechaçadas com as costas das mãos cinzentas de cimento. Ao mesmo tempo, a voz imprecisa apenas chamava as crianças para junto de si, porque não havia mesmo mais nada a fazer. Era uma tarde de domingo e certamente se tornou inesquecível para quem abdicou do imperdível Show de Calouros, para presenciar aquele drama familiar.

Pareavam na idade, mas viviam situações completamente distintas. Filho único cercado de cuidados pelo pai e mimos pela mãe, Antônio assistira a tudo debruçado no muro de sua casa. Dali assistia também às coças que Bira aplicava em Patolino, quando este, depois de tantos gritos do pai, reaparecia ao anoitecer, não se sabe de onde. Do muro, Antônio assistia a tudo. A vida no vilarejo, as brincadeiras de rua das outras crianças, os ensaios de quadrilha e o inevitável namoro dos casaizinhos que formavam par na dança. As decorações para a copa do mundo, os preparativos do bloco carnavalesco e a confecção das alegorias. A agitação dos grupos de bate-bolas, dos quais, discretamente, morria de medo. A tudo Antônio assistia do muro. O mundo do outro lado o seduzia, mas o zelo excessivo dos pais o continha, sob a prevenção de que "essas coisas de rua não levam ninguém a lugar nenhum. Tem é que estudar". 
Antônio olhava, à distância, desejoso, a vida que os pais lhe evitavam desfrutar. Os adultos parecem esquecer que foram crianças e perdem de vista a beleza e o desejo desse olhar. A criançada via coloridos os desenhos animados nas tevês em preto e branco. O azul era lindo da cabine do almirante Nelson, no submarino de Viagem ao fundo do mar, assim como era verdinha a grama nos jogos do Brasil, com sua camisa amarela canarinho. Nos olhos verdes de Antônio não era diferente, e na pele escura de Patolino enxergava as cores da verdadeira liberdade, que ingenuamente chegava invejar.

Foi uma tarde gelada de terça-feira, o mês era maio, e era véspera do aniversário de Antônio. Patolino havia saído pelas nove, comendo metade de uma bisnaga ensebada de Claybom. Como de costume bateu boca com Juba Maluco, intriga rotineira que quase sempre acabava em briga. Desceu a rua passando pela Rural velha do Pedro da Cana, parou na esquina, como que procurando o que fazer, e daí em diante sumiu no mundo. Quando se ouvia no rádio o som da Ave Maria, Bira tanto gritou pelo Jorge, que até o nome, de tão roucamente pronunciado, já parecia outro. “Ô Roooorre!". O fato é que aquele foi o último fim de tarde que o negro Bira chamou pelo filho.

O tempo seguiu seu passar de rio longo, ora sereno, ora corrido, e Antônio, aos vinte anos de idade, não mais assistia à vida do muro. Agora era necessário vivê-la. O cuidado dos pais o havia preparado para o futuro. Nunca levou uma surra como via o 
menino Patolino levar, foi sempre bom aluno, filho pródigo. Nunca teve seu nome gritado aos quatro ventos, sob o medo do que o aguardava, como o Patolino. Nunca andou descalço e sem camisa, entrando no valão para repor a bola em jogo na pelada do campinho. Nunca nem fora brincar no campinho. Nunca soube, aliás, que fim levou o Patolino, desde aquela tarde gelada de maio. Mas também nunca o esqueceu. E sempre, sempre, em seu íntimo, trouxe retida a admiração que sentia por ele. Porque criança só se pode ser uma vez, e criança não respeita o futuro. Por isso, talvez, viva sempre feliz. Antônio, por mais que se realize profissionalmente no futuro, por mais experiente que se torne, vai sempre desejar as experiências desconhecidas de Patolino. No fundo da alma, vai sempre querer saber aonde ele ia, o que fazia e por onde andava durante um dia todo, até que ouvisse o inconfundível e inesquecível brado:

_ O Joooooorge! 